\title{
Slope Stability Analysis to Develop Correlations between Different Soil Parameters and Factor of Safety Using Regression Analysis
}

\author{
Muhammad Israr Khan, Shuhong Wang* \\ School of Resources and Civil Engineering, Northeastern University, 110819, Shenyang, China
}

Received: 3 October 2020

Accepted: 5 December 2020

\begin{abstract}
This paper generally deals with the slope stability analysis of soil and an easy way to stabilize the slope to achieve high shear strength. Correlations between Factor of Safety (FS) and soil parameters i.e. cohesion, friction and unit weight are developed in this paper. Correlations among factor of safeties in natural, stepped and nailed form are also developed using linear regression analysis. Soil is not a homogeneous material and its properties are changing in different conditions and in different places. In case of slopes, there are many ways to stabilize it by nailing or stepping techniques. In this paper, both these methods are investigated in detail and compared to each other to know that which method gives better result. The graphs which shows the percent improvement of safety value are provided in the result section. This paper is providing a summary of the slopes safety issues having different soil properties. A software namely Slide is used for Limit Equilibrium (LE) analysis of the pre-defined soil slope model. For correlations, MS Excel and SPSS software are used. The correlations equations are provided in the results section.
\end{abstract}

Keywords: correlations, factor of safety, nailing, stepping, slope stability analysis, slide

\section{Introduction}

Land sliding problem exists throughout the world especially in hilly areas. Many people have lost their lives and gets injured due to this issue. There are many examples of land sliding in the history which caused a very huge damage to human lives, houses, roads and other areas of economic importance. In Italy on October 09, 1963 a landslide that slid into the reservoir

*e-mail: wangshuhong@mail.neu.edu.cn behind the Vajont dam, which was responsible for approximately 2000 victims in the surrounding area [1]. Petley [2] enlisted 2,620 non-seismically triggered landslides that caused 32,322 fatalities all over the world between 2004 and 2010.

Keeping this problem in considerations, many researchers worked on the causes of land sliding and provided many solutions for overcoming this problem. Javankhoshdel discussed the factor of safety for cohesive soils to develop charts for estimating the factor of safety [3].

However it is observed that due to the variation of soil properties from place to place, the factor of safety may differ too. Therefore, it needs to be studied 
and stabilized according to the specific site condition. The two best ways to stabilize any slope is:

- Insert nails inside the slope called Nailing.

- Make the slope in step form called Stepping.

Proper soil nailing technique was first introduced in France. In case of nailing, previous studies show that the results in Limit Equilibrium Method are dependent on the nail and bond length. Slopes having longer nail length are more stable [4]. Similarly due to the presence of soil nails, the continuous slip plane is prevented. The stresses in the nails are mobilized through the soil nail interaction. The earth pressure generated from the potential sliding area is transferred to the soil nails by the soil nail heads [5]. The various schemes for slope reinforcement using anchor cable (bolt) shows that a better reinforcement effect can be achieved when more reinforcement is applied to the position characterized by high stress level of sliding zone [6]. Soil nailing is an accepted, economical, top down construction technique that increases the overall shear strength of unsupported soils in situ through the installation of closely spaced reinforcing bars (nails) into the soil/ rock [7]. Shanmugapriya concluded that for soil slope with steepness of $30^{\circ}, 45^{\circ}$ and $60^{\circ}$, the best factor of safety found with soil nail inclination (to the horizontal) of $60^{\circ}, 50^{\circ}$ and $40^{\circ}$ respectively [8]. Other researchers also worked from different aspects using soil nailing technique. All these methods are based on stabilizing the slope through nailing technique which is expensive compare to stepping technique. Although the factor of safety achieved by both these methods is not very different in many cases.

A comparative study is done in this paper for all the three forms i.e. natural, stepping and nailing condition. This paper provides the overall summary and comparison between the factor of safeties in all three conditions.

Most of the previous researchers worked on specific soil type and one way of stabilizing the soil was considered. In this paper, the Factor of safety for a predefined slope is checked in three different ways such as natural form, stepping form and nailed form to know the percent improvement in factor of safety as well as the shear strength of soil. These three methods are compared to each other in graphical form. The shear strength graphs are also provided in this paper which clearly shows the percent improvement of the shear strength with the stepping and nailing techniques. Graphs are also provided which shows the comparison of factor of safety in natural, stepping and nailed conditions.

Correlations among the factor of safety values with the variation of cohesion, friction and unit weight are developed. Also correlations among factor of safety in natural, stepped and nailed form are developed.

Thus the results achieved in this paper are:

1. Correlations between soil parameters in different conditions.

2. Variation in shear strengths in graphical form.
3. Variation in Factor of Safeties value in graphical form.

\section{Materials and Methods}

All the parameters such as cohesion, friction are providing the shear resistance to failure and the shear strength. Clay and clayey sand were considered in this research and silty material is not taken into account as correlations are not available for making reliable estimates of the undrained shear strength of silt [9]. Table 1 shows the material properties used in this paper. These are the material properties of local Chinese soil.

For slope stability analysis, normally conventional or slices methods is used to get the factor of safety for slopes. For instance, in 1955, Bishop proposed the modified Bishop method, an effective and simple method to analyze circular slip surfaces. In this method, the factor of safety is defined as the potential sliding along a failure surface. The Bishop simplified method satisfies vertical force equilibrium equations for every slice and the overall moment equilibrium equations about the center point of the trial circular surface.

Table 1. Material properties.

\begin{tabular}{|c|c|c|c|c|}
\hline $\begin{array}{l}\text { Material } \\
\text { Number }\end{array}$ & $\begin{array}{c}\text { Cohesion } \\
(\mathrm{KPa})\end{array}$ & $\begin{array}{l}\text { Friction } \\
\qquad(\phi)\end{array}$ & $\begin{array}{c}\text { Unit } \\
\text { Weight } \\
\left(\mathrm{KN} / \mathrm{m}^{3}\right)\end{array}$ & Material Type \\
\hline 1 & 10 & 27 & 13 & Clay \\
\hline 2 & 11 & 28 & 13.6 & Clay \\
\hline 3 & 12 & 29 & 14.2 & Clay \\
\hline 4 & 13 & 30 & 14.8 & Clay \\
\hline 5 & 14 & 31 & 15.4 & Clay \\
\hline 6 & 15 & 32 & 16 & Clay \\
\hline 7 & 16 & 33 & 16.6 & Clay \\
\hline 8 & 17 & 34 & 17.2 & Clay \\
\hline 9 & 18 & 35 & 17.8 & Clay \\
\hline 10 & 19 & 36 & 18.4 & Clay \\
\hline 11 & 1 & 25 & 16.366 & Clayey Sand \\
\hline 12 & 2 & 26 & 16.464 & Clayey Sand \\
\hline 13 & 3 & 27 & 16.562 & Clayey Sand \\
\hline 14 & 4 & 28 & 16.758 & Clayey Sand \\
\hline 15 & 5 & 29 & 16.856 & Clayey Sand \\
\hline 16 & 6 & 30 & 16.954 & Clayey Sand \\
\hline 17 & 7 & 31 & 17.052 & Clayey Sand \\
\hline 18 & 8 & 32 & 17.15 & Clayey Sand \\
\hline 19 & 9 & 33 & 17.248 & Clayey Sand \\
\hline 20 & 10 & 34 & 17.346 & Clayey Sand \\
\hline
\end{tabular}




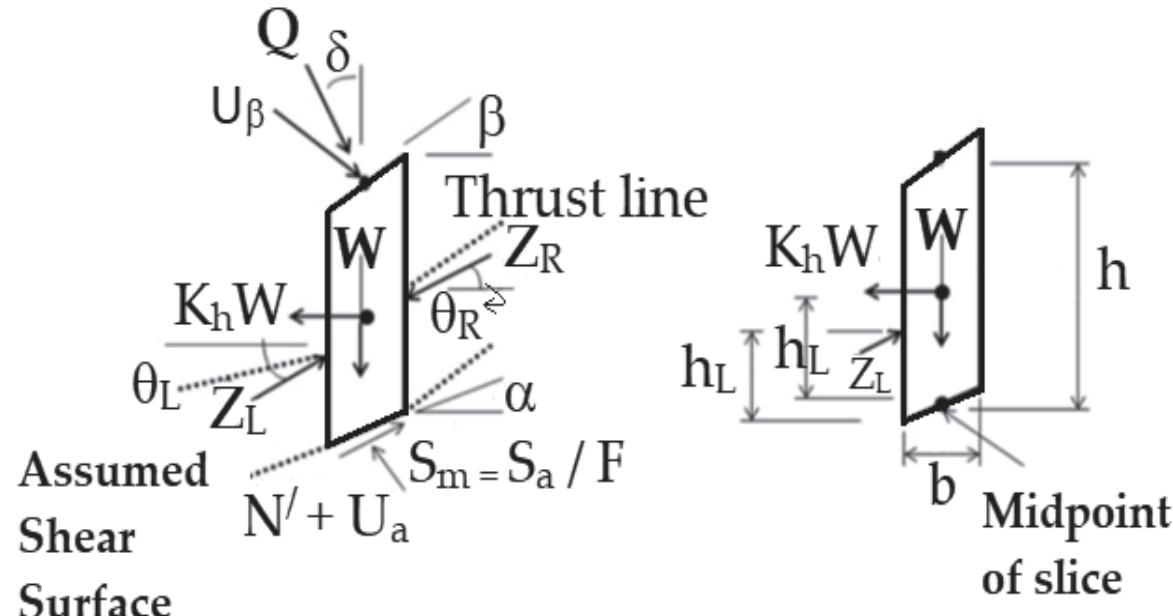

Fig. 1. Assumed slice layout and forces acting on it.

Where:

$\mathrm{F}=$ factor of safety $=\mathrm{C}+\mathrm{N} / \tan \phi$,

$\mathrm{Sm}=$ Strength mobilized

$\mathrm{N} /=$ Effective normal force

$\mathrm{hL}=$ Height of force $\mathrm{ZL}$

$\alpha=$ base slice inclination

$\delta=$ surcharge inclination

$\theta \mathrm{L}=$ force angle (left inter-slice)

$\mathrm{W}=$ slice weight

$\mathrm{U} \beta=$ surface water force

$\mathrm{Kh}=$ seismic coefficient (Horizontal)

$\mathrm{Sa}=$ Strength available

$\mathrm{b}=$ slice width

$\mathrm{Q}=$ external surcharge

$\mathrm{hR}=$ Height of force $\mathrm{ZR}$

$\beta=$ top slice inclination

hc $=$ slice centroid height

$\theta \mathrm{R}=$ force angle (right inter-slice)

$\mathrm{U} \alpha=$ pore water pressure

$\mathrm{Kv}=$ seismic coefficient (Vertical)

The horizontal forces are not considered at every slice, the Bishop simplified method also assumes zero interslice shear forces. This method is simple and gives value for factor of safety very near to any finite element method. It is therefore applicable to a wide range of practical problems. Fig. 1 shows the slices assumed in this method. All forces acting on the slice are mentioned in it.

In Bishop simplified method, the final equation for the slope factor of safety after all the assumptions is:

$$
\begin{gathered}
\mathrm{F}=\frac{\sum_{i-1}^{n}\left(C+N^{\prime} \tan \phi\right)}{\sum_{i-1}^{n} A_{5}-\sum_{i-1}^{n} A_{6}-\sum_{i-1}^{n} A_{7}} \\
\mathrm{~A} 5=[\mathrm{W}(1-\mathrm{ku})+\mathrm{U} \beta+\mathrm{Q} \cos \delta] \mathrm{R} \sin \alpha \\
\mathrm{A} 6=[\mathrm{U} \beta \sin \beta+\mathrm{Q} \sin \delta](\cos \alpha-h / R) \\
\mathrm{A} 7=\mathrm{kh} \mathrm{W}(\cos \alpha-h / R) \\
\text { Methodology, Modelling and Analysis } \\
\text { Using Slide }
\end{gathered}
$$

Most of the researchers used Strength reduction method for slope stability analysis as observed in the literature review $[10,11]$. This method is also known as $\phi$ - c reduction method. This method is also very useful in computing the pseudo-static analysis especially for cohesive materials [12]. This technique is widely used in major geotechnical softwares. The same method is used for analysis in this paper. Slide is a software used for Limit equilibrium analysis of slopes. Slide software is used to get results using different methods such as Bishop simplified, Janbu simplified, Janbu corrected, Fellenius, Spencer, Morgenstern-Price and LoweKarafiath etc. In this paper, Bishop simplified, Janbu, Spencer and Fellenius methods are considered out of which Fellenius method is preferred for the factor of

Find material properties such as cohesion, friction and unit weight etc.

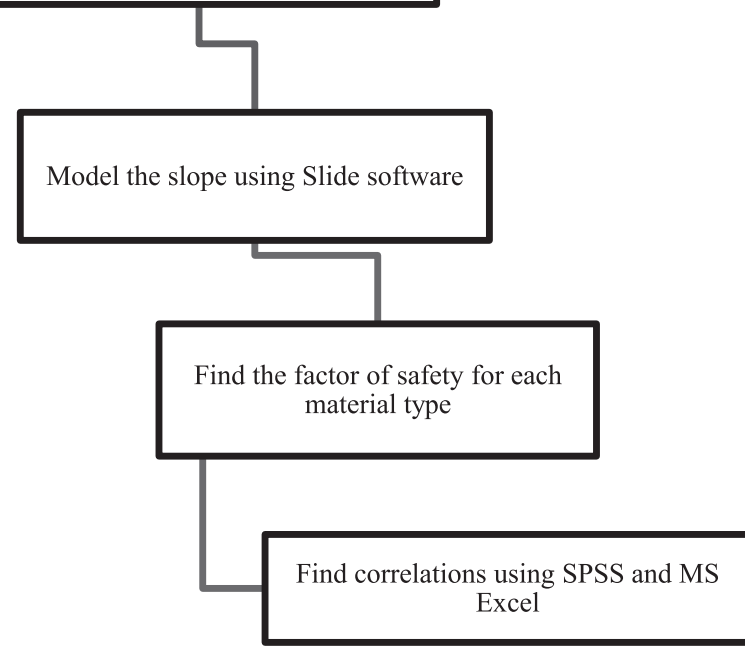

Fig. 2. Paper flowchart. 
Table 2. Slope coordinates.

\begin{tabular}{|c|c|}
\hline$X$ & $Y$ \\
\hline 0 & 0 \\
\hline 27 & 0 \\
\hline 27 & 5 \\
\hline 16 & 5 \\
\hline 10 & 16 \\
\hline 0 & 16 \\
\hline
\end{tabular}

safety achieved as it gives the least value for the factor of safety. The methodology flowchart of this paper is shown in Fig. 2.

\section{Slope Model}

Table 2 shows the coordinates of the soil slope model.

Figs 3, 4 and 5 shows the slope model considered in natural, stepped and nailed form.

The anchored capacity of each nail was $100 \mathrm{KN}$ and it is end anchored nail type material. The length of nail was kept in a range of $3 \mathrm{~m}$ to $8 \mathrm{~m}$. Figs 6,7 and 8 shows the overall Shear strength achieved in natural, stepped and nailed form respectively.

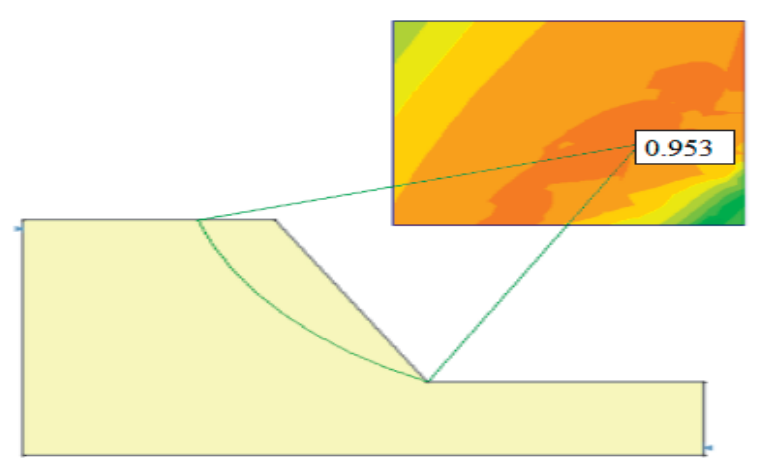

Fig. 3. Slope model in Natural form.

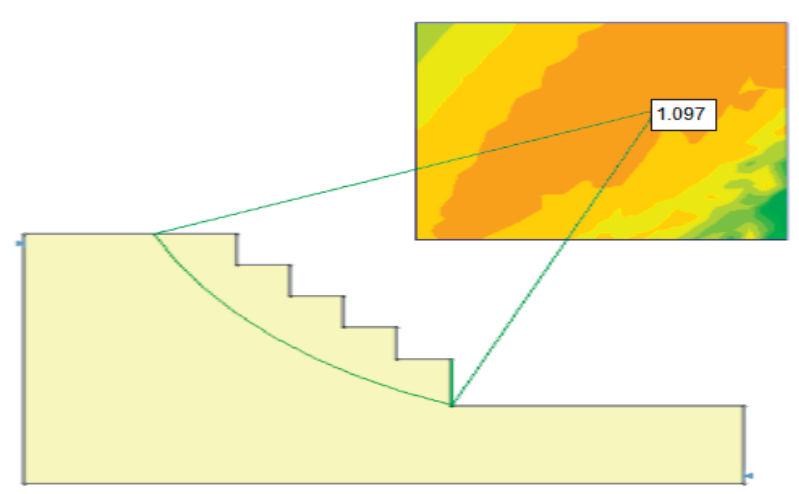

Fig. 4. Slope model in Stepped form.

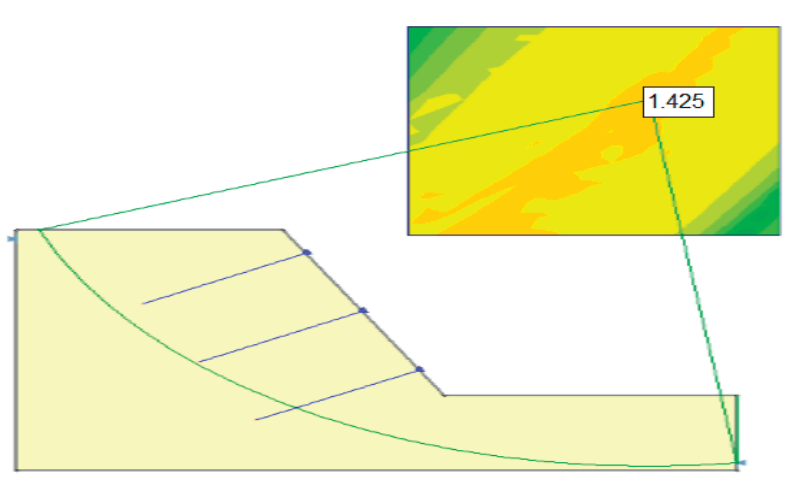

Fig. 5. Slope model in Nailed state.

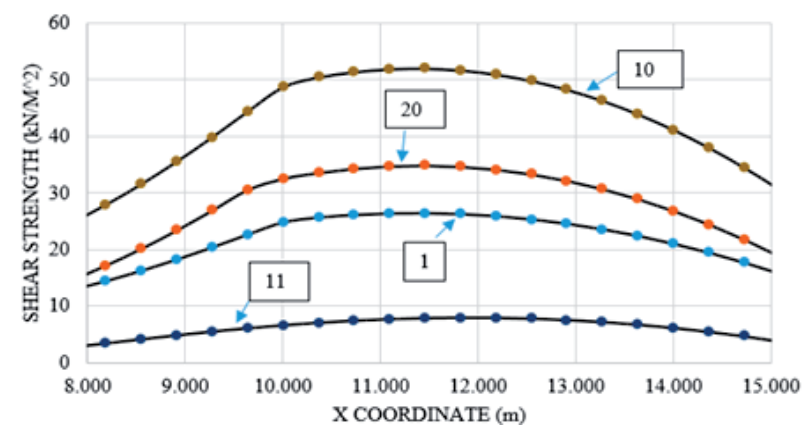

Fig. 6. Overall shear strength in case of natural slope for M 1, 10,11 and 20.

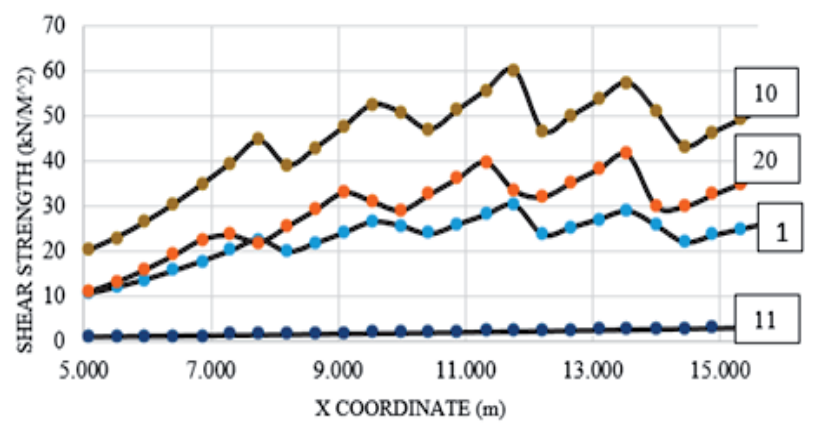

Fig. 7. Overall shear strength in case of stepped slope for M 1, 10,11 and 20 .

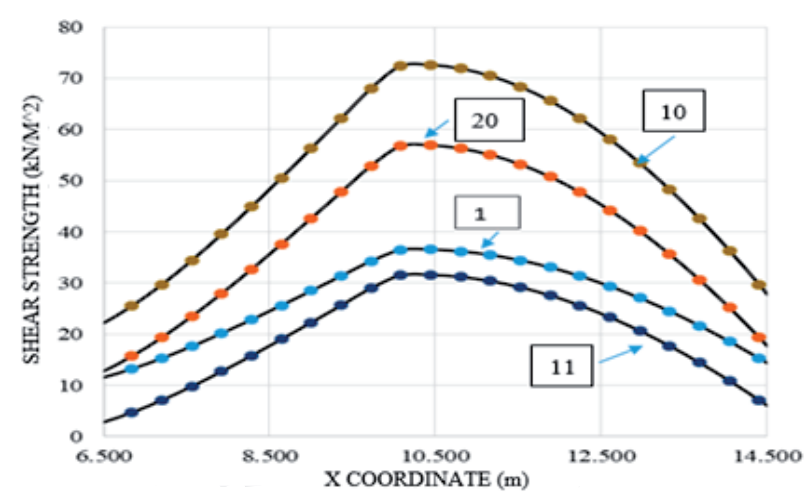

Fig. 8. Overall shear strength in case of nailed form for $\mathrm{M} 1,10$, 11 and 20. 
Table 3. FS in all the three cases.

\begin{tabular}{|c|c|c|c|c|}
\hline Material Number & FS (Natural) & FS (Stepped) & FS (3m Nailed) & FS (8m Nailed) \\
\hline 1 & 0.953 & 1.097 & 1.091 & 1.545 \\
\hline 2 & 0.998 & 1.149 & 1.142 & 1.609 \\
\hline 3 & 1.042 & 1.199 & 1.192 & 1.673 \\
\hline 4 & 1.084 & 1.248 & 1.24 & 1.736 \\
\hline 5 & 1.125 & 1.296 & 1.288 & 1.799 \\
\hline 6 & 1.165 & 1.342 & 1.334 & 1.845 \\
\hline 7 & 1.204 & 1.388 & 1.38 & 1.889 \\
\hline 8 & 1.242 & 1.433 & 1.425 & 1.932 \\
\hline 9 & 1.28 & 1.478 & 1.471 & 1.975 \\
\hline 10 & 1.317 & 1.522 & 1.515 & 2.017 \\
\hline 11 & 0.372 & 0.361 & 0.598 & 0.763 \\
\hline 12 & 0.456 & 0.537 & 0.661 & 0.922 \\
\hline 13 & 0.529 & 0.643 & 0.725 & 1.006 \\
\hline 14 & 0.596 & 0.737 & 0.787 & 1.086 \\
\hline 15 & 0.66 & 0.809 & 0.85 & 1.169 \\
\hline 16 & 0.723 & 0.881 & 0.914 & 1.252 \\
\hline 17 & 0.786 & 0.951 & 0.977 & 1.336 \\
\hline 18 & 0.849 & 1.018 & 1.041 & 1.419 \\
\hline 19 & 0.912 & 1.085 & 1.105 & 1.503 \\
\hline 20 & 0.973 & 1.152 & 1.169 & 1.586 \\
\hline
\end{tabular}

Table 3 shows the factor of safety values achieved for all the three condition during this analysis.

Maximum shear strength graphs are plotted for $3 \mathrm{~m}$ and $8 \mathrm{~m}$ only. It is clear from table 3 that in case of increasing the nail length, the factor of safety also increased. In case of material 1, the factor of safety is increased from 1.091 (unsafe) to 1.545 (safe). Similarly in all other cases, the factor of safety is increased up to much extent. Compare to clay, the factor of safety in case of clayey sand is not increased that much. It is because if the cohesion in soil gets decreased, the slope as a whole is not acting like one body.

\section{Results and Discussions}

To study the stability prediction of Letlhakane mine, Kayesa [13] used the geomos slope monitoring system. The geomos slope monitoring system is a continuous and automatic system which runs for 24 hours. Evolutionary Polynomial Technique (EPR) was developed by Ahangar-Asr et al. [14] to predict the FS. This model was very useful in predicting the behavior of slopes. For analyzing FS, Mohamed et al. [15, 16] used Geo Studio and compared with the fuzzy logic system. The results were found very close to the target. Erzin and Cetin [17] used artificial neutral network and multiple linear regression to calculate the FS in case of a typical artificial slope. This slope was also subjected to seismic forces. The predicted results showed that the results were highly precise. Chae et al. [18] developed equations considering the depth ratio in case of rainfall induced slopes. The results were compared with the previous steady state hydrological model and landslide inventory graphs, they concluded that the predicted approach gives very satisfactory results. Using the theory of mass approach, Firmansyah et al. [19] predicted the run out distance of rotational type slope. They concluded that the unit weight plays a very important role in the factor of safety issues. Many other researchers recently provided many other techniques to know about the land sliding phenomena [20-30]. In this paper, the correlations are developed to predict the factor of safety in stepped and nailed form. The significant level of the results is that these correlations could be used to predict the safety of slope in advance. Before failure of any slope, it could be checked that how much this slope is safe. It includes all types of earthen slopes such as dams or slopes in hilly areas. 
Table 4. Correlations in Natural, Stepped and Nailed form.

\begin{tabular}{|c|c|c|c|}
\hline \multicolumn{3}{|c|}{ Natural } & \multirow[b]{2}{*}{ (5) } \\
\hline Cohesion Variation & $\mathrm{FS}=0.0443 \mathrm{c}+0.5154$ & $\mathrm{R}^{2}=0.99$ & \\
\hline Friction Variation & $\mathrm{FS}=0.0215 \varphi+0.3697$ & $\mathrm{R}^{2}=0.99$ & (6) \\
\hline Unit weight Variation & $\mathrm{FS}=-0.0222 \gamma+1.2242$ & $\mathrm{R}^{2}=0.98$ & (7) \\
\hline \multicolumn{4}{|c|}{ Stepped } \\
\hline Cohesion Variation & $\mathrm{FS}=0.0476 \mathrm{c}+0.623$ & $\mathrm{R}^{2}=1$ & $(8)$ \\
\hline Friction Variation & $\mathrm{FS}=0.0278 \varphi+0.3431$ & $\mathrm{R}^{2}=0.99$ & (9) \\
\hline Unit weight Variation & $\mathrm{FS}=-0.0233 \gamma+1.3851$ & $\mathrm{R}^{2}=0.98$ & (10) \\
\hline \multicolumn{4}{|c|}{ Nailed } \\
\hline Cohesion Variation & $\mathrm{FS}=0.0367 \mathrm{c}+0.9578$ & $\mathrm{R}^{2}=1$ & (11) \\
\hline Friction Variation & $\mathrm{FS}=0.0452 \varphi+0.098$ & $\mathrm{R}^{2}=0.99$ & (12) \\
\hline Unit weight Variation & $\mathrm{FS}=-0.0273 \gamma+1.6795$ & $\mathrm{R}^{2}=0.99$ & (13) \\
\hline
\end{tabular}

...where:

FS is Factor of Safety

$\mathrm{c}$ is cohesion

$\varphi$ is friction

$\gamma$ is unit weight

$\mathrm{R}^{2}$ is the percentage variation coefficient

\section{Correlations between Factor of Safety and Soil Parameters}

One of the main outcome of this paper is the development of correlations between factor of safety with varying the values of cohesion, friction and unit weight separately. Cohesion and friction are the main parameters used in soil stability analysis and many researchers work on it from different aspects [31]. The correlation equations are developed separately for natural form, stepped form and nailed form. Table 4 shows the correlation equations.

\section{Correlations between Factor of Safeties in Case of Natural, Stepped and Nailed Slope}

The correlations are developed using SPSS software. There are four different types of correlations, such as:

Table 5. SPSS details of coefficients in case natural factor of safety is dependent variable.

\begin{tabular}{|c|c|c|c|c|c|c|c|}
\hline \multirow{2}{*}{ Model } & \multicolumn{2}{|c|}{$\begin{array}{c}\text { Unstandardized } \\
\text { Coefficients }\end{array}$} & \multirow{2}{*}{$\begin{array}{c}\text { Standardized } \\
\text { Coefficients }\end{array}$} & \multirow{2}{*}{$\mathrm{t}$} & \multirow{2}{*}{ Sig. } & \multicolumn{3}{|c|}{$\begin{array}{c}95.0 \% \text { Confidence Interval } \\
\text { for B }\end{array}$} \\
\cline { 2 - 8 } & $\mathrm{B}$ & Std. Error & Beta & & & Lower Bound & Upper Bound \\
\hline & -0.237 & 0.017 & & -13.579 & 0.000 & -0.274 & -0.200 \\
\hline Constant & -0.037 & 0.068 & -0.043 & -0.550 & 0.590 & -0.182 & 0.107 \\
\hline FS Stepped & 0.216 & 0.076 & 0.208 & 2.859 & 0.011 & 0.056 & 0.377 \\
\hline FS in Case of Nailed Slope (3 m) & 0.634 & 0.078 & 0.835 & 8.087 & 0.000 & 0.468 & 0.801 \\
\hline
\end{tabular}

- Correlation in which natural factor of safety is considered as dependent variable while stepped and nailed $(3 \mathrm{~m}$ and $8 \mathrm{~m})$ are considered as independent variables.

Table 5 shows the coefficients generated by SPSS and equation 14 is the correlation in which natural factor of safety is dependent variable while stepped and nailed $(3 \mathrm{~m}$ and $8 \mathrm{~m})$ are dependent variable for same slope.

$$
\begin{gathered}
\mathrm{FS}_{\text {Natural }}=-0.237-0.037\left(\mathrm{FS}_{\text {Stepped }}\right) \\
+0.216\left(\mathrm{FS}_{3 \mathrm{~m} \mathrm{nailed}}\right)+0.634\left(\mathrm{FS}_{\text {8m nailed }}\right)
\end{gathered}
$$

- Correlation in which stepped factor of safety is considered as dependent variable while natural and nailed $(3 \mathrm{~m}$ and $8 \mathrm{~m}$ ) are considered as independent variables.

The correlation is as follows: 


$$
\begin{gathered}
\mathrm{FS}_{\text {Stepped }}=-0.347-0.495\left(\mathrm{FS}_{\text {Natural }}\right) \\
+0.173\left(\mathrm{FS}_{3 \mathrm{~m} \text { nailed }}\right)+1.116\left(\mathrm{FS}_{8 \mathrm{~m} \text { nailed }}\right)
\end{gathered}
$$

- Correlation in which nailed $(3 \mathrm{~m})$ factor of safety is considered as dependent variable while natural and stepped factor of safeties are considered as independent variables.

$$
\begin{aligned}
& \mathrm{FS}_{3 \mathrm{~m} \mathrm{Nailed}}=0.378+1.563\left(\mathrm{FS}_{\text {Natural }}\right) \\
& +0.094\left(\mathrm{FS}_{\text {Stepped }}\right)-0.539\left(\mathrm{FS}_{8 \mathrm{~m} \text { nailed }}\right)
\end{aligned}
$$

- Correlation in which nailed (8m) factor of safety is considered as dependent variable while natural and stepped factor of safeties are considered as independent variables.

The correlation is as follows:

$$
\begin{aligned}
\mathrm{FS}_{8 \mathrm{~m} \mathrm{Nailed}}=0.330 & +1.267\left(\mathrm{FS}_{\text {Natural }}\right)+0.168\left(\mathrm{FS}_{\text {Stepped }}\right) \\
& -0.149\left(\mathrm{FS}_{3 \mathrm{~m} \text { nailed }}\right)
\end{aligned}
$$

\section{Correlations between Two Variables}

From same data available in table 3, correlations between two variables are also generated, which are given below one by one:

- Correlation in which natural factor of safety is dependent and stepped factor of Safety is independent variable.

$$
\mathrm{FS}_{\text {Natural }}=-0.017+0.873\left(\mathrm{FS}_{\text {Stepped }}\right)
$$

- Correlation in which natural factor of safety is dependent and nailed $(3 \mathrm{~m})$ factor of Safety is independent variable.

$$
\mathrm{FS}_{\text {Natural }}=-0.221+1.036\left(\mathrm{FS}_{3 \mathrm{~m} \text { nailed }}\right)
$$

- Correlation in which natural factor of safety is dependent and nailed $(8 \mathrm{~m})$ factor of Safety is independent variable.

$$
\mathrm{FS}_{\text {Natural }}=-0.229+0.760\left(\mathrm{FS}_{8 \mathrm{~m} \text { nailed }}\right)
$$

- Correlation in which stepped factor of safety is dependent and nailed $(3 \mathrm{~m})$ factor of Safety is independent variable.

$$
\mathrm{FS}_{\text {Stepped }}=-0.224+1.178\left(\mathrm{FS}_{3 \mathrm{~m} \text { nailed }}\right)
$$

- Correlation in which stepped factor of safety is dependent and nailed $(8 \mathrm{~m})$ factor of Safety is independent variable.

$$
\mathrm{FS}_{\text {Stepped }}=-0.234+0.865\left(\mathrm{FS}_{8 \mathrm{~m} \text { nailed }}\right)
$$

Equation 5 to equation 13 are correlations between factor of safety and soil parameters while equation 14 to 22 are correlations between factor of safety in natural, stepped and nailed form in different conditions. These correlations could be used to know about the factor of safety in different conditions.

\section{Improvement Percentage in Factor of Safety and Shear Strength Value}

The statistical analysis in graphical form are shown in Figs 6 to 12. Change in value of FS in all the three conditions can be observed from the graphs below. The difference between the FS for $3 \mathrm{~m}, 4 \mathrm{~m}, 5 \mathrm{~m}, 6 \mathrm{~m}, 7$ $\mathrm{m}$ and $8 \mathrm{~m}$ nail length can be observed in the graph shown in Fig. 9 while Fig. 10 shows the factor of safety graph in case of all the three conditions together such as natural, stepping and nailing condition.

For any of the material, the FS can be calculated from these graphs. With the change in nail length, the FS is also increased linearly.

The statistical results can be checked in these graphs. From Figs 8 and 9, it is very clear that stepping can improve the factor of safety more than natural form and nailing can improve the factor of safety more than stepping. Material 10 is clay having highest cohesion, friction and unit weight in this analysis. And material 20 is clayey sand having highest value

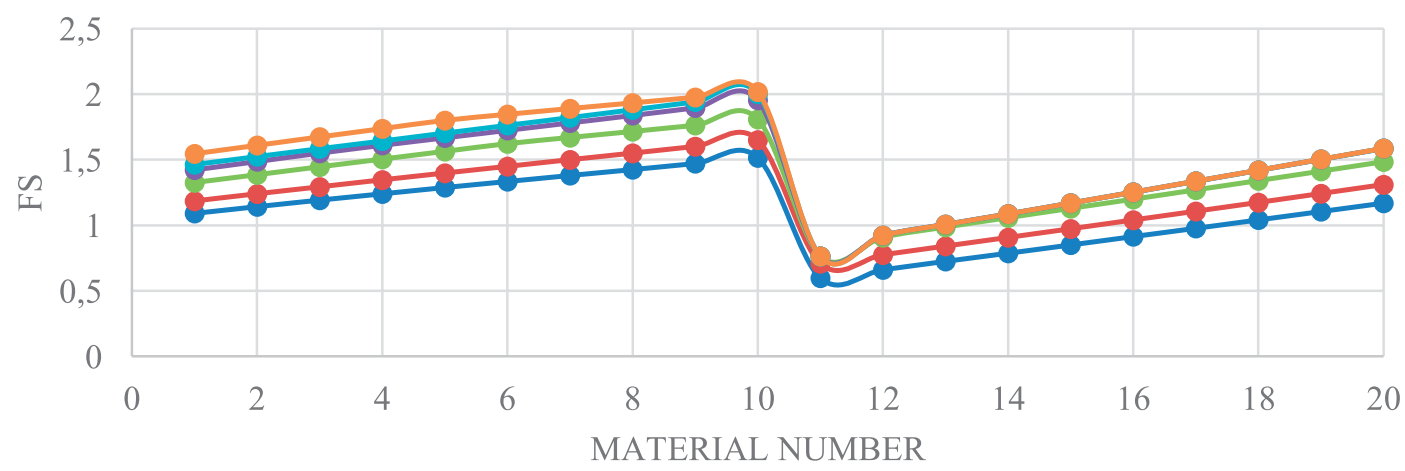

$\longrightarrow 3 \mathrm{~m}$ NAIL $\longrightarrow 4 \mathrm{~m}$ NAIL $\longrightarrow 5 \mathrm{~m}$ NAIL $-6 \mathrm{~m}$ NAIL $-7 \mathrm{~m}$ NAIL $\longrightarrow 8 \mathrm{~m}$ NAIL

Fig. 9. Factor of safety in case of nailed slope (3 $\mathrm{m}$ to $8 \mathrm{~m}$ ). 
of cohesion, friction and unit weight. These two materials are taken out of twenty materials to check the improvement in factor of safety after applying different stabilizing techniques. It is clear from the bar graph shown in Fig. 11 that value of factor of safety in case of material 10 is improved from minimum $13 \%$ to maximum $35 \%$ while in case of material 20, the factor of safety is improved from minimum $16 \%$ to maximum $39 \%$ after applying stepping and nailing techniques. Fig. 11 shows a comparison in the factor of safety values between material 10 and material 20.

From the graph shown in Fig. 12, it is clear that the shear strength can be improved from a minimum of $13 \mathrm{KN} / \mathrm{m}^{2}$ up to a maximum of $77 \mathrm{KN} / \mathrm{m}^{2}$ in case of material 10. While it can be improved from a minimum of $7 \mathrm{KN} / \mathrm{m}^{2}$ up to a maximum of $82 \mathrm{KN} / \mathrm{m}^{2}$ in case of material 20 .

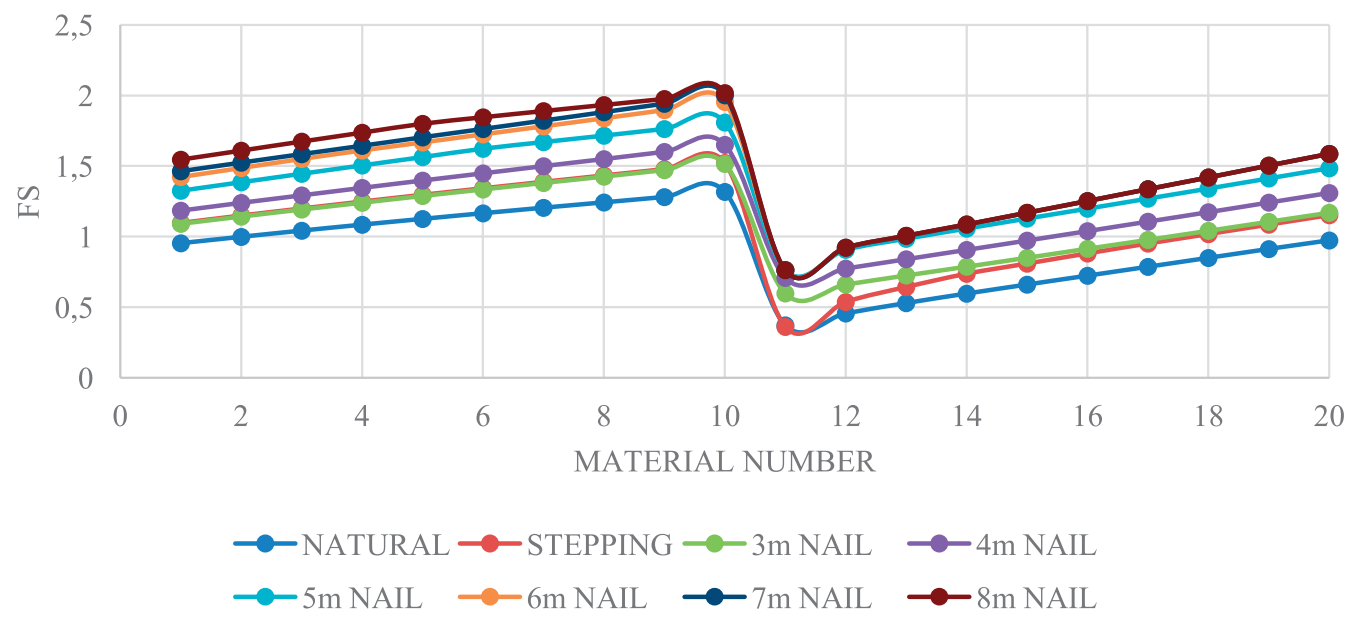

Fig. 10. Factor of safety in all the three conditions such as natural, stepping and nailing.

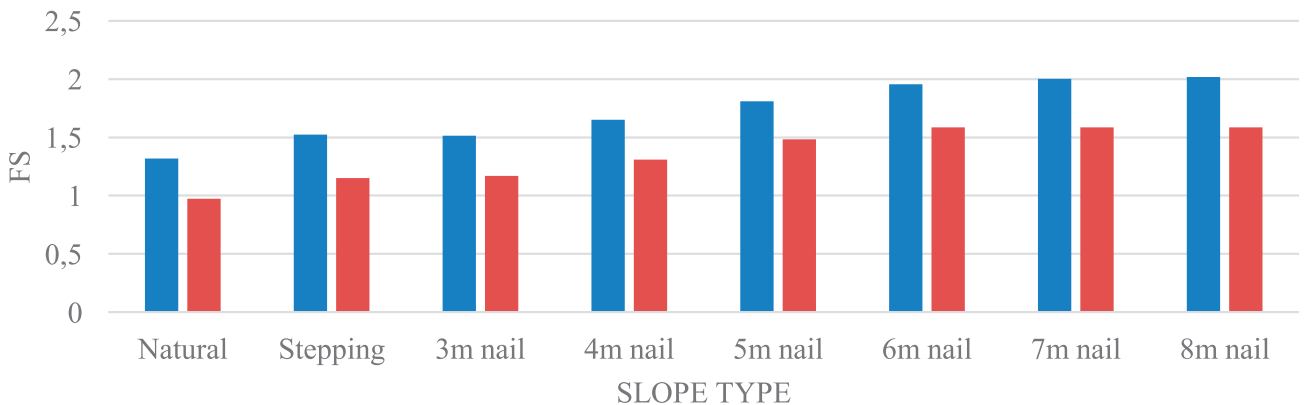

- MATERIAL 10 MATERIAL 20

Fig. 11. Comparison of factor of safety for material 10 and 20.

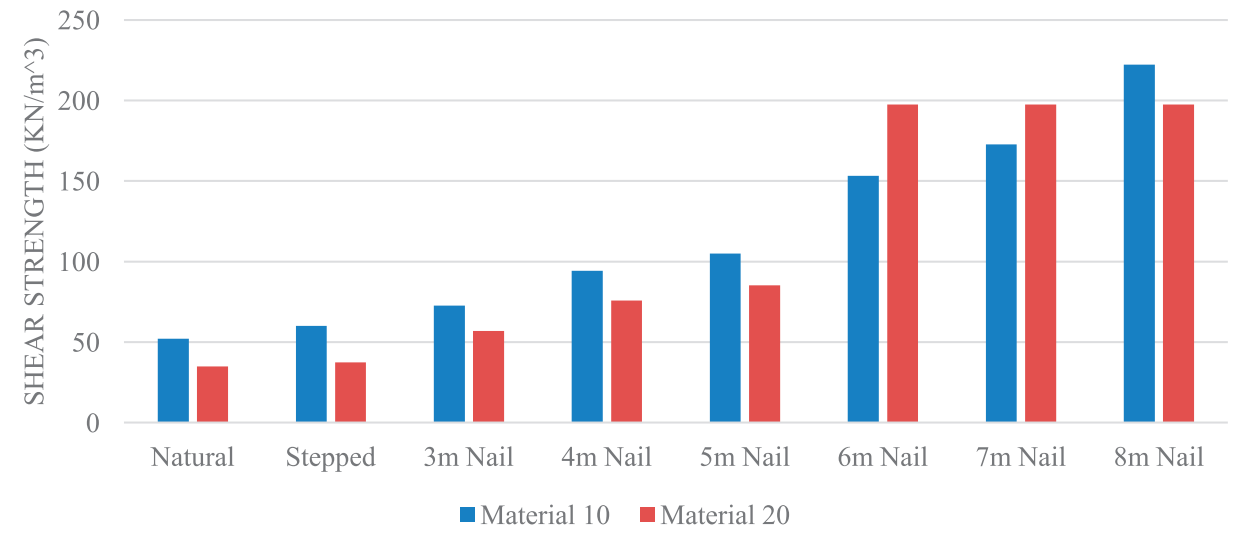

Fig. 12. Shear strength comparison for material 10 and 20. 
The correlations shown in Table 4 are new contribution in field of slope stability analysis. Similarly figure 9 and 10 are also new contribution in this field. It could be used for any slope stability projects keeping the material properties in considerations.

\section{Conclusions}

The hypothesis of this paper are concluded as follows:

1. The correlations shown in Table 4 are useful to find the unknown values in soil slope stability analysis such as factor of safety, cohesion, friction and unit weight. Similarly equations 14 to 22 are useful correlations in case of finding the factor of safety in different conditions such as natural, stepping and nailed form.

2. The shear strength of the slope is improved from $13 \mathrm{KN} / \mathrm{m}^{2}$ to $77 \mathrm{KN} / \mathrm{m}^{2}$ and $7 \mathrm{KN} / \mathrm{m}^{2}$ to $82 \mathrm{KN} / \mathrm{m}^{2}$ in case of clay and clayey sand respectively. This shows that increasing the shear strength of soil can easily increase the factor of safety up to the required extent.

3. Any slope can be stabilized according to the requirement of the site such as in this paper the slope factor of safety was improved from minimum 13\% to maximum $35 \%$ in case of clay and $16 \%$ to $39 \%$ in case of clayey sand.

4. Stepping technique is not very suitable in the case of cohesionless soil as it causes a single step to fail which ultimately become the basis for the failure of the whole slope. Hence it gives very low factor of safety.

5. In case of nailing, if the nail length reach the critical failure plane, it gives the maximum shear strength further increase in length does not cause any increase in the shear strength of soil as clear from graph shown in figure 10 in which the $6 \mathrm{~m}, 7 \mathrm{~m}$ and $8 \mathrm{~m}$ nails are giving almost the same shear strength in case of cohesionless soil.

Correlations between other soil parameters such as poison ratio, elasticity of soil, void ratio etc. can also be extracted using the same methodology. This work can be done using Finite element analysis for comparing the results of both Limit equilibrium method and Finite Element Method. To change the nail properties, such as instead of end anchoring, geotextile can be used to check the factor of safety for different slopes. Applying the same techniques for slope stabilizing in case of pore water pressure such as if the water table exists inside the slope. In this condition, the analysis will show whether the stepping technique is better or nailing for cohesive and cohesionless soil. Although much work is done in this context but specifically for stepping and nailing techniques with changing soil properties will be a new and useful work in this regard.

\section{Acknowledgement}

This work was conducted with supports from the National Natural Science Foundation of China (Grant Nos. U1602232 and 51474050), Doctoral Scientific Research Foundation of Liaoning Province (Grant No. 20170540304 and 20170520341), China Scholarship Council (Grant No. 201806080103), Key Research and Development Program of Science and Technology in Liaoning Province, China (Grant No. 2019JH2/10100035), the Fundamental Research Funds for the Central Universities (Grant No. N170108029).

\section{Conflict of Interest}

The authors declare no conflict of interest.

\section{References}

1. SCOPPETTUOLO M.R., CASCINI I.L., BABILIO I.E. Typical displacement behaviours of slope movements. Landslides. 17, 1105, 2020. Corresponding Email: mscoppettuolo@unisa.it

2. PETLEY D. Global patterns of loss of life from landslides. Geology, 40 (10), 927, 2012. Corresponding Email: editing@geosociety.org

3. JAVANKHOSHDEL S., BATHURST R.J. Simplified probabilistic slope stability design charts for cohesive and c-ø soils. Canadian Geotechnical Journal, 51 (9), 1033, 2014. Corresponding Email: s.javan.khoshdel@queensu.ca

4. RAWAT S., GUPTA A. K. Analysis of a Nailed Soil Slope Using Limit Equilibrium and Finite Element Methods. International Journal of Geosynthetics and Ground Engineering, 2, 1, 2016. Corresponding Email: saurabh. rawat@juit.ac.in

5. DENG G., XU T., CHEN R., LU Z., LIU J. Numerical Analysis on Stabilizing Mechanism of Soil Nails in Steep Fill Slopes Subjected to Rainfall Infiltration Using a Hypoplastic Model. Arabian Journal for Science and Engineering. 43, 5079, 2018. Corresponding Email: redaktion@springerprofessional.de

6. YANG G., ZHONG Z., ZHANG Y., FU X. Optimal design of anchor cables for slope reinforcement based on stress and displacement fields. Journal of Rock Mechanics and Geotechnical Engineering. 7(4), 411, 2015. Corresponding Email: 1084242143@qq.com

7. MIDHULA J., CHANDRAKARAN S. Numerical Simulation of Soil Nailed Structures. International Journal of Engineering research \& Techology. 4 (8), 525, 2015. Corresponding Email: info@ijert.org

8. SHANMUGAPRIYA D., SITI N.J. Slope stability analysis under different soil nailing parameters using the SLOPE/W software. Journal of Physics: Conference Series. 1174, 1, 2019. Corresponding Email: priya30shan@gmail.com

9. DUNCAN J.M., WRIGHT S.G., BRANDON T.L. Soil strength and slope stability, $2^{\text {nd }}$ Ed. 2005. Corresponding Author: Duncan, J.M

10. LIN H., XIONG W., CAO P. Stability of soil nailed slope using strength reduction method. Eur. J. Environ. Civ. Eng. 17 (9), 872, 2013. Corresponding Email: hanglin@csu.edu. cn 
11. FAWAZ A., FARAH E., HAGECHEHADE F. Slope stability analysis using numerical modelling. American J. Civ. Eng. 2 (3), 60, 2014. Corresponding Email: alifawaz2014@gmail.com

12. SHUKHA R., BAKER R. Design implications of the vertical pseudo-static coefficient in slope analysis. Comput. Geotech. 35 (1), 86, 2008. Corresponding Email: baker@technion.ac.il

13. KAYESA G. Prediction of slope failure at Letlhakane mine with the Geomos slope monitoring system. . Int. Symposium on Stabil. Rock Slopes Open Pit Min. Civ. Eng. 605, 2006. Corresponding Email: georgekayesa@ hotmail.com

14. AHANGAR-ASR A., FARAMARZI A., JAVADI A. A. A new approach for prediction of the stability of soil and rock slopes. Eng. Comput. 27 (7), 878, 2010. Corresponding Email: a.a.javadi@ex.ac.uk

15. MOHAMED T., KASA A., MUKHLISIN M. Prediction of slope stability using statistical method and fuzzy logic. Online J. Sci. Technol. 2 (4), 68, 2012a. Corresponding Email: tarigmohal@yahoo.com

16. MOHAMED T., KASA A., TAHA M. R. Fuzzy logic system for slope stability prediction. Int. J. Adv. Sci. Eng. Inform Technol. 2(2), 38, 2012b. Corresponding Email: tarigmohal@yahoo.com

17. ERZIN Y., CETIN T. The use of neural networks for the prediction of the critical factor of safety of an artificial slope subjected to earthquake forces. Scientia Iranica. 19 (2), 188, 2012. Corresponding Email: yusuf.erzin@bayar. edu.tr

18. CHAE B.G., LEE J.H., PARK H.J., CHOI J. A method for predicting the factor of safety of an infinite slope based on the depth ratio of the wetting front induced by rainfall infiltration. Nat. Hazards Earth Syst. Sci. 15, 1835, 2015. Corresponding Email: hjpark@sejong.ac.kr

19. FIRMANSYAH, TOHARI A., LATIEF F.D. Prediction of landslide run-out distance based on slope stability analysis and center ofmass approach. IOP Conf. Ser: Earth Environ. Sci. 29, 1, 2016. Corresponding Email: firmansyah72@, student.upi.edu

20. HUANG F., YIN K., HUANG J., GUI L., WANG P. Landslide susceptibility mapping based on self-organizingmap network and extreme learning machine. Eng. Geol. 223, 11, 2017. Corresponding Email: yink1@126.com

21. SHIRZADI A., BUI D.T., PHAM B.T., SOLAIMANI K., CHAPI K., KAVIAN A., SHAHABI H., REVHAUG I. Shallow landslide susceptibility assessment using a novel hybrid intelligence approach. Environ. Earth Sci. 76, 1, 2017. Corresponding Email: K.chapi@uok.ac.ir

22. PHAM B.T., JAAFARI A., PRAKASH I., BUI D.T. A novel hybrid intelligent model of support vector machines and the MultiBoost ensemble for landslide susceptibility modeling. Bullet of Eng. Geol. Environ. 78, 2865, 2018 Corresponding Email: phamthaibinh@tdt.edu.vn

23. AKGUN A. A comparison of landslide susceptibility maps produced by logistic regression, multi-criteria decision, and likelihood ratio methods: a case study at İzmir, Turkey. Landslides. 9, 93, 2012. Corresponding Email: aykut.akgun@ktu.edu.tr

24. PHAM B.T., PRADHAN B., TIEN B.D., PRAKASH I., DHOLAKIA M.B. A comparative study of different machine learning methods for landslide susceptibility assessment: a case study of Uttarakhand area (India). Environ. Model Software. 84, 240, 2016. Corresponding Email: binhpt@utt.edu.vn

25. YOUSSEF A.M., POURGHASEMI H.R., POURTAGHI Z.S., AL-KATHEERI M.M. Landslide susceptibility mapping using random forest, boosted regression tree, classification and regression tree, and general linear models and comparison of their performance at Wadi Tayyah Basin, Asir Region, Saudi Arabia. Landslides. 13, 839, 2016. Corresponding Email: hr.pourghasemi@ shirazu.ac.ir

26. BUEECHI E., KLIMES J., FREY H., HUGGEL C., STROZZI T., COCHACHIN A. Regional-scale landslide susceptibility modelling in the Cordillera Blanca, Peru a comparison of different approaches. Landslides. 16, 395, 2019. Corresponding Email: emanuel.bueechi@uzh.ch

27. CATANI F., LAGOMARSINO D., SEGONI S., TOFANI V. Landslide susceptibility estimation by random forests technique: sensitivity and scaling issues. Nat. Hazards Earth Syst. Sci. 13 (11), 2815, 2013. Corresponding Email: filippo.catani@unifi.it

28. CATANI F., TOFANI V., LAGOMARSINO D. Spatial patterns of landslide dimension: a tool for magnitude mapping. Geomorphology. 273, 361, 2016. Corresponding Email: filippo.catani@unifi.it

29. KHAN M.I., WANG S., ZHANGZE. Analysis of earth fill hydraulic dam with varying crest length and permeability to develop correlations. International Conference on Civil and Hydraulic Engineering. 304 (5), 2019. Corresponding Email: 1727011@stu.neu.edu.cn

30. KHAN M.I., WANG S. Comparing the various slope stability methods to find the optimum method for calculating factor of slope safety. International Conference on Energy, Material Science and Environment Engineering. 480, 2020. Corresponding Email: 1727011@ stu.neu.edu.cn

31. BUREAU D., MOURGUES R., CARTWRIGHT J. Use of a new artificial cohesive material for physical modelling: application to sandstone intrusions and associated fracture networks. J. Struct. Geol. 66, 223, 2014. Corresponding Email: denisbureau72@hotmail.fr 